\title{
Effectiveness of wellbeing instruction on the knowledge and attitude of university students on pre-marriage screening and counseling
}

\author{
Hala Abdelfattah Ali \\ Women's Health and Maternity Nursing, Faculty of Nursing Kafrelsheikh University, Kafrelsheikh, Egypt \\ Corresponding author: dr.halafttah@yahoo.com
}

\begin{abstract}
Aim of the study: This study aimed to evaluate the effectiveness of wellbeing instruction on the knowledge and attitude of university students on pre-marriage screening and counseling. Methods: A quasi-experimental design was used which was conducted at one medical Nursing and one non-medical Commerce faculty at Kafrelsheikh University, Egypt. A purposive sample of one thousand female students enrolled in this study. One tool was used which was self-administered questionnaire. Results: There was a statistical significance with total knowledge and attitude. The aggregate knowledge score expanded from $23.3 \%$ to $54 \%$ among medical students, and from $21 \%$ to $41 \%$ among non-medical students and the significance was statistically high. The elevating attitude significantly increased from $54.7 \%$ to $66 \%$ among nursing students and from $49 \%$ to $57.5 \%$ among commerce students. Conclusion: It can be inferred that, even though there was a difference in the level of knowledge for all students in the two groups after wellbeing instruction, they had inadequate information about pre-marriage screening and counseling. But above one half from each group communicated a great and motivating attitude toward pre-marriage screening and counseling. Recommendations: On the glow of these findings, it is prescribed to lead wellbeing training administrations about pre-marriage screening among students of secondary schools in Kafrelsheikh Governorate to expand the general population mindfulness and impact their states of attitude towards pre-marriage screening and counseling administrations.
\end{abstract}

Keywords: Knowledge, Attitude, Pre-marriage counseling

\section{Introduction}

Pre-marriage screening is the most important assessment before marriage with a specific end goal to make a distinction if there are any heritable blood diseases, for example, sickle cell anemia and Thalassemia, and some highly infectious diseases, for example, hepatitis B and C and AIDS ${ }^{1}$. This is keeping in mind the final goal to give a nursing guide to the expectation couples and to give choices before wedding with the point of helping them to look forward to a healthy family ${ }^{2}$. Pre-marriage screening is a stick out along with the most critical methodologies for curative action of genetic disorders, inborn irregularities, and a few nursing and psychosocial marriage issues ${ }^{3}$. It can offer a chance to intercede, as indicated by the recognized threat. This intervention integrates vaccination, advising in regard to conducting counting those identified with AIDS and dissimilar diseases, sustenance, hereditary directing, the assistance concerning contraception, a variation of constant illness, treatment of contaminations, and pharmaceutical to shrink teratogenic threat ${ }^{4-6}$. Moreover, general relationship excellence, with illustration risks factors for afterward marriage problems and expanding the personal fulfillment for couples and families who continue together ${ }^{7}$.

Pre-marriage counseling is furthermore the most fitting method, as it is, for the most part, adequate from the spiritual and ethical perception and its insignificant wellbeing, and practical requirements 8. The principal part of counseling concerns hemoglobinopathy's sickle cell disease or thalassemia. These sicknesses are a noteworthy general medical problem in the Mediterranean countries, the Middle
East, the Indian subcontinent, Asia, tropical Africa, and the Caribbean. Since indicated by the World Health Organization in the order of two hundred million and forty individuals are heterozygous for acquired hemoglobinopathies including thalassemia and sickle cell illness ${ }^{3-6}$. The example of marriage relationship activates and dissimilar types of close relative relation's unions, prompting development in the event of passive hereditary differentiates ${ }^{8}$. Hereditary clutters are exceptionally normal furthermore; they are deeply persistent in the all-inclusive community of the Kingdom of Saudi Arabia. It is most likely that the execution of pre-marriage enticing illness screening is and destructive and horrible task size of cost and effect. Pre-marriage counseling will be counseling given by a marriage and family advisor or someone from the ministry to make possible the couple to get ready for marriage ${ }^{4,9-11}$.

Pre-marriage counseling means to enable the couple to look at uncertain issues, illuminate individual qualities, and bring relationship desires to build their chances of having a productive marriage. Couples are similarly urged to enhance their communication and develop their relationship character to help relationships get better ${ }^{4,9-11}$. The responsibility of the health providers is profuse wellbeing instruction which is one of the devices that offer people with the information, abilities, and encouragement to settle on a more advantageous way of life decisions. There is a major necessitate of information related to conceptive wellbeing even among instructed people. The conceptive wellbeing organization is falling behind current attitudes and requirements of academy students. Despite the fact those students' dispositions towards sexual issues are liberal; their approaching about regenerative wellbeing and pre-marriage information is as yet limited. 
A first lesson step for the outline of the rightful wellbeing instruction procedure is to know how much the objective gathering thinks about medical issues and what their attitude towards this imperative component of wellbeing concern ${ }^{12}$.

The World Health Organization has arranged a few measures to prevent hereditary illnesses including wellbeing training and the change of community learning and attitude towards the control of inborn hereditary sicknesses ${ }^{6,8}$. Wellbeing instruction is a fundamental method for enhancing people in the general view of newly presented wellbeing interventions 7,9 . In general, studies directed about premenstrual syndrome revealed the low learning of young people about this important issue. Also, there is an absence of instructive programs about the premenstrual syndrome in Jeddah. An ongoing report led in King doom Saudi Arabia among huge members summarized that the normal occurrence of AIDS, hepatitis B and C virus, starting information from screening tests for hemoglobinopathies point to massive provincial contrasts ${ }^{11}$. Also, probably elevated chance marriage was distinguished among two points one percent of the screened future life partners, with eighty-six percent professional taking places with the marriage even though high hazard status ${ }^{12}$. A complete epidemiological assessment including wellbeing training effort for university students about the premenstrual syndrome is intently required. Enhancing the people groups' learning will improve their comprehension and involve men needed for diminishing the number of relational unions among transporters. It is vital to assess and enhance the information and attitude of female students since they are the future mothers all together to guarantee safe parenthood. The progression and security of their wellbeing particularly from conceptive wellbeing risks are exceedingly basic. A variety of examinations were directed in Egypt and different nations tending to learn the outlook of youth towards pre-marriage counseling however smaller number of examinations were intended to evaluate the effect of wellbeing training interference among youth in Egypt ${ }^{12}$.

This study aimed to evaluate the effectiveness of wellbeing instruction on the knowledge and attitude of university students on pre-marriage screening and counseling. To achieve the aim of this study, one hypothesis was formulated and tested. Female nursing students may have higher knowledge and attitude scores than female commerce students after receiving pre-marriage counseling.

\section{Subjects and Methods}

\section{Research design}

A quasi-experimental research design was used. It is a research design searching for knowledge and attitude of students in situations in which complete control is not possible. It lacked at least one of the three characteristics of the experimental design which were manipulation, control, and randomization. The pretest was done before the introduction of the new teaching approach. The present study was performed at one medical faculty which was the Faculty of Nursing and one non-medical faculty which was the Faculty of Commerce at Kafrelsheikh University, Egypt. The existent field of work was completed on the first of December, 2018 to the finish of February, 2019.

The target variable in this study was the female students of Faculties of Nursing and Commerce Universities, Egypt. The study was based on the data obtained from preceding study that assessed the knowledge and performance scores before and after education and considering the level of significance of $5 \%$ and power of study of $80 \%$, the sample size was calculated using the following formula: $\mathrm{n}=2 \mathrm{Z} \alpha / 2+\mathrm{Z} \beta 2 \times \mathrm{p}$ 1-p/difference of proportions2=997.1, and hence, in this study we enrolled 1000 participants. The cumulative number of students in the Faculty of Nursing University was 1800 students. It contains four levels; the aggregate number of female students is 1257 . The aggregate number of students in the Faculty of Commerce, University was 4000 students. It contains four levels; the aggregate number of female students is 2500. A purposive sample comprised of female students from the Faculty of Nursing and Faculty of Commerce was selected for the study. Inclusion criteria included female students at age ranges from 17 to 23 years. Exclusion criteria included married females.

\section{Recruitment technique}

Female students ( $n=1000)$ were assigned for group education. Every female student suitable for the incorporation criteria and had an acceptance to contribute in the current study was enlisted for the study. Students were chosen on random handing over by selecting the female students from each level of two faculties first, second, third\& fourth according to the inclusion criteria. Students $n=1000$ were divided into two groups. Group 1 of the medical faculty $n=400$ and group 2 of the non-medical faculty $n=600$ were assigned for the counseling session.

\section{Tools used for data collection}

The researchers have developed tools after reviewing linked literature. It was written in the English language. The questionnaire was distributed and piloted on volunteer students out of the main sampling of the study and any fundamental modifications were done. One tool was built by the researcher, which is self-administered questionnaire pre and post instructive program. It was considered by the researchers after reviewing related literature. It consisted of four parts. Part I was concerned with socio-demographic characteristics of the students such as age in years, residence place, and mother's education. Part II was fretful with students' knowledge regarding pre-marriage screening and counseling and their sources of knowledge. It includes the Definition and significance of pre-marriage screening and counseling, components of pre-marriage screening and counseling package, suitable time of pre-marriage screening and counseling, providers of pre-marriage screening, and seats that give of pre-marriage screening and counseling. Part III (an attitude assessment scale) in which a threepoint Likert-scale agree, neutral and disagree was created to evaluate the students' response to attitude statements towards pre-marriage screening and counseling among medical and non-medical groups. It comprised of fourteen items to which the students were requested to react to one of the decisions. Part IV (scoring system) in which he students answered the identified knowledge which was scored and also ascertained. As indicated by the appropriate responses, students' reactions were assessed utilizing the model key answer sheet which was already arranged by the researcher. Students' scoring of knowledge related to pre-marriage screening and counseling was named takes after: two points for complete correct answers for each inquiry, one point for deficient right answers, while the wrong answer was scored zero. The aggregate items of knowledge. They are six items were given twelve grades for finishes the right answers. Total students' score which ranges from seven to twelve grades sixty percent and more were delegated having a high level of knowledge, scores from four to six grades from thirty-five percent to under sixty percent for finish right answers were depicted as an average level of knowledge while a score under 4 grades $<$ thirty-five percent for finish right answers were described as a low level of knowledge.

A scoring for students' attitudes toward pre-marriage screening and counseling was comprised of given three points for agreeing, two 
points for neutral, and one point for disagreeing. A scoring was given to each inquiry and the aggregate attitude score was forty-two points. The score of equivalent to or more than twenty five-sixty percent passes on a positive attitude towards pre-marriage counseling, while an aggregate score of fifteen $-<$ twenty-five thirty-five percent $-<$ sixty percent passes on neutral attitude and an aggregate score of under fifteen thirty-five percent passes on a negative attitude towards pre-marriage guiding, utilizing the model key answer sheet which was arranged by the researcher.

\section{Validity and Reliability}

The present investigation's tool was submitted to five qualified nursing specialists in the field to test the substance legality of the tools, changes were completed by the scholastic nursing specialists' judgment on the clarity of sentences, what's more, the suitability of the content. Tools reliability was tried utilizing the Alpha Cronbach test. The tool of knowledge, internal consistency among the questionnaire items was 0.80 Cronbach's alpha $(\alpha)$ and it was considered within the acceptable range. While its outcome was 0.85 for Tool of attitude which indicates accepted reliability of the tools Bending, 1954.While Tool of evaluating score, Internal consistency among the questionnaire items was 0.90 Cronbach's alpha $(\alpha)$ decisions.

\section{Administrative design}

In the wake of taking the approval from Scientific and Ethical Research Committee which audited and affirmed the examination an official letter elucidating the reason for the current study and tolerating the procedure of data collection was coordinated from the dignitary of the Faculty of Nursing to the senior member of nonmedical workforce asking for their endorsement for data gathering in $(1 / 1 / 2018)$.

\section{Ethical consideration}

A written agreement of the students to join in the current study was acquired. All students were educated that their participation was intentional and that the gathered information would be utilized for the reason for the present investigation, and additionally for their advantage.

\section{Pilot study}

A pilot study was completed on $10 \% 100$ female students at the beforehand specified settings to evaluate the present study tools for its clearness, legitimacy, and the time required to fill the apparatuses. Likewise, fundamental alterations such as (marriage status and students' age) were finished. The pilot group was expelled from the study sample.

\section{Procedure}

\section{Assessment phase}

Initially, the researchers divide the participants into small groups as indicated by their educated time table. The researcher holds a meeting with each group in their faculty during one of their free classes or between lectures to set up themselves, what's more, the researcher introduces herself to the students and rapidly clarified the nature of the study. After acquiring the written agreement from the students to share in the present study and flow think about, the researcher gave an illustration and clarification about the assessment tool questions to the entire class. At that point, the self-administered questionnaire and attitude assessment scale were disseminated to every understudy to assess their knowledge and attitude toward pre-marriage screening and counseling. The questionnaire took around twenty to twenty-five minutes to be completed.

\section{Implementation phase}

Consequent to assessing the students' knowledge and attitude, the total sample was divided into twenty groups. Each group ranged from forty-five to fifty. Health teaching training sessions were given to the students as lectures and group discussion by utilizing varying media aids, every session of one-hour duration. Every week, two or three groups got two lectures, with a total time of eight weeks for the entire groups. The lectures included data about the definition, significance of pre-marriage counseling or care, the target group, providers of premarriage counseling, what's more, pre-marriage care package which included counseling, examination, investigations, pre-marriage vaccination, genetic counseling and places that provide pre-marriage care. An extra fifteen minutes were doled out toward the end of the lecture for an open discussion with the students about this theme. Handouts containing brief focuses on pre-marriage counseling and care were appropriated to students towards the end of the session.

\section{Evaluation phase}

The researcher utilized alike questionnaire of assessment stage four weeks after actualizing the educational sessions with alike students that took part beforehand, keeping in mind the end goal to identify the level of students' knowledge after health education and if there were any changes in their attitude.

\section{Statistical analysis}

Information was gathered, coded, organized, and investigated, by utilizing the SPSS computer PC program application for measurable examination. Unmistakable measurements were utilized to figure rates and frequencies. Chi-square X2 test was utilized to evaluate the measurable critical contrasts between factors. A remarkable P-value was considered when it is under 0.05 and it was considered very high when P-value is not exactly or approach 0.0113 .

\section{Results}

As shown in Table 1, more than seventy-five percent of seventy-nine point five percent of the nursing group's age runs between 20-23 years when contrasted with $61.70 \%$ of the commerce group. Besides, the greater part of medical students ninety-six percent who lived in urban areas contrasted with ninety-one point seven percent of non-medical students. Short of what one section of medical students $44.0 \%$ who have mothers' education at university level contrasted with nineteen point seven percent from commerce students separately.

As appeared in table 2, a statistically significant difference was revealed pre and post-program related to pre-marriage knowledge recognized with the definition, importance, contents, and, reasonable time of pre-marriage screening and counseling. The right and complete answers lengthened from thirty percent to sixty point five percent, from 41.00 to $57.00 \%$, from eight-point five to twenty-three percent and thirty-four to forty-seven percent among nursing students separately. Likewise, among the commerce students, the right and complete answers lengthened from twenty-three point seven to fiftyfour percent, from thirteen point seven to thirty-six point three percent, from seven-point three to nineteen point seven percent and from twenty-nine point three to thirty-four point seven percent individually. 
Table 1. Allocation of the [nursing and commerce students] by their socio demographic characteristics.

\begin{tabular}{|c|c|c|c|c|c|}
\hline \multirow[t]{2}{*}{ Items } & \multirow[t]{2}{*}{ Categories } & \multicolumn{2}{|c|}{$\begin{array}{l}\text { Nursing students } \\
\quad(\mathrm{n}=400)\end{array}$} & \multicolumn{2}{|c|}{$\begin{array}{l}\text { Commerce students } \\
\qquad(\mathrm{n}=600)\end{array}$} \\
\hline & & $\mathrm{N}$ & $\%$ & $\mathrm{~N}$ & $\%$ \\
\hline \multicolumn{6}{|c|}{ Student's age (years) } \\
\hline & $<20$ years & 82 & 20.50 & 230 & 38.30 \\
\hline & $20-23$ years & 159 & 79.5 & 370 & 61.7 \\
\hline \multicolumn{6}{|c|}{ Student's residence } \\
\hline & Urban area & 384 & 96 & 550 & 91.70 \\
\hline & Rural area & 16 & 4 & 50 & 8.30 \\
\hline \multicolumn{6}{|c|}{ Education of mothers } \\
\hline & Read and write & 20 & 5 & 120 & 20 \\
\hline & Preparatory level & 96 & 24 & 282 & 47 \\
\hline & Secondary level & 108 & 27 & 86 & 14.30 \\
\hline & University level & 176 & 44 & 112 & 18.70 \\
\hline
\end{tabular}

Table (2). Division of the nursing and commerce students] related to pre marriage knowledge pre and post counseling.

\begin{tabular}{|c|c|c|c|c|c|c|c|c|c|c|}
\hline \multirow{3}{*}{ Items } & \multicolumn{4}{|c|}{ Pre marriage counseling } & \multicolumn{4}{|c|}{ Post marriage counseling } & \multirow{3}{*}{$\begin{array}{c}\begin{array}{c}\text { Nursing } \\
\text { students }\end{array} \\
\mathrm{X}^{2} \\
\mathrm{P}\end{array}$} & \multirow{3}{*}{$\begin{array}{c}\begin{array}{c}\text { Commerce } \\
\text { students }\end{array} \\
\mathrm{X}^{2} \\
\mathrm{p}\end{array}$} \\
\hline & \multicolumn{2}{|c|}{$\begin{array}{l}\text { Nursing } \\
(\mathrm{n}=400)\end{array}$} & \multicolumn{2}{|c|}{$\begin{array}{c}\text { Commerce } \\
(\mathrm{n}=600)\end{array}$} & \multicolumn{2}{|c|}{$\begin{array}{l}\text { Nursing } \\
(\mathrm{n}=400)\end{array}$} & \multicolumn{2}{|c|}{$\begin{array}{c}\text { Commerce } \\
(\mathrm{n}=600)\end{array}$} & & \\
\hline & $\mathrm{N}$ & $\%$ & $\mathrm{~N}$ & $\%$ & $\mathrm{~N}$ & $\%$ & $\mathrm{~N}$ & $\%$ & & \\
\hline \multicolumn{11}{|c|}{ Pre-marriage screening and counseling definition } \\
\hline $\begin{array}{c}\text { Complete } \\
\text { proper answer }\end{array}$ & 120 & 30 & 142 & 23.70 & 242 & 60.50 & 324 & 54 & \multirow[t]{2}{*}{15.3} & \multirow[t]{2}{*}{17.102} \\
\hline $\begin{array}{c}\text { Incomplete } \\
\text { proper answer }\end{array}$ & 136 & 34 & 212 & 35.30 & 150 & 37.50 & 224 & 37.30 & & \\
\hline $\begin{array}{c}\text { Incorrect or } \\
\text { don't know }\end{array}$ & 144 & 36 & 246 & 41 & 8 & 2 & 52 & 8.70 & $0.002 *$ & $0.001^{*}$ \\
\hline \multicolumn{11}{|c|}{ Importance of pre-marriage screening and counseling } \\
\hline $\begin{array}{c}\text { Complete } \\
\text { proper answer. }\end{array}$ & 164 & 41 & 82 & 13.70 & 228 & 57 & 218 & 36.30 & 12.58 & 10.52 \\
\hline $\begin{array}{c}\text { Incomplete } \\
\text { proper answer. }\end{array}$ & 142 & 35.50 & 162 & 27 & 126 & 31.50 & 320 & 53.30 & \multirow[t]{2}{*}{$0.001 *$} & \multirow[t]{2}{*}{$0.0047^{*}$} \\
\hline $\begin{array}{c}\text { Incorrect or } \\
\text { don't know }\end{array}$ & 94 & 23.50 & 356 & 59.30 & 46 & 11.50 & 62 & 10.30 & & \\
\hline \multicolumn{11}{|c|}{ Components of pre-marriage screening and counseling package } \\
\hline $\begin{array}{c}\text { Complete } \\
\text { proper answer. }\end{array}$ & 34 & 8.50 & 44 & 7.30 & 92 & 23.0 & 118 & 19.70 & 18.25 & 19.25 \\
\hline $\begin{array}{c}\text { Incomplete } \\
\text { proper answer. }\end{array}$ & 170 & 42.50 & 196 & 32.70 & 182 & 45.50 & 276 & 46 & \multirow[t]{2}{*}{$0.001^{*}$} & \multirow[t]{2}{*}{$0.001 *$} \\
\hline $\begin{array}{c}\text { Incorrect or } \\
\text { don't know }\end{array}$ & 196 & 49 & 360 & 60 & 126 & 31.50 & 206 & 34.30 & & \\
\hline \multicolumn{11}{|c|}{ Appropriate time of pre-marriage screening and counseling } \\
\hline $\begin{array}{c}\text { Complete } \\
\text { proper answer. }\end{array}$ & 136 & 34 & 176 & 29.30 & 188 & 47 & 208 & 34.70 & 6.89 & 5.68 \\
\hline $\begin{array}{c}\text { Incomplete } \\
\text { proper answer. }\end{array}$ & 154 & 38.50 & 196 & 32.70 & 176 & 44 & 310 & 51.70 & \multirow[t]{2}{*}{$0.024^{*}$} & \multirow[t]{2}{*}{$0.038^{*}$} \\
\hline $\begin{array}{l}\text { Incorrect or } \\
\text { don't know }\end{array}$ & 110 & 27.50 & 228 & 38 & 36 & 9 & 82 & 13.60 & & \\
\hline
\end{tabular}


Table 3. Allocation of the nursing and commerce students by their knowledge according to the providers of pre marriage counseling and seats that provide pre marriage screening and counseling.

\begin{tabular}{|c|c|c|c|c|}
\hline \multirow[t]{2}{*}{ Items } & \multicolumn{2}{|c|}{ Nursing students $(\mathrm{n}=400)$} & \multicolumn{2}{|c|}{ Commerce students $(\mathrm{n}=600)$} \\
\hline & $\mathrm{N}$ & $\%$ & $\mathrm{~N}$ & $\%$ \\
\hline \multicolumn{5}{|c|}{ Provider of pre-marriage screening. } \\
\hline General practitioner & 190 & 47.50 & 298 & 49.60 \\
\hline Nurse & 110 & 27.50 & 74 & 12.30 \\
\hline Social worker & 128 & 32 & 74 & 12.30 \\
\hline $\begin{array}{c}\text { Auditory visual } \\
\text { media }\end{array}$ & 88 & 22 & 56 & 12.60 \\
\hline Don't know & 60 & 15.0 & 128 & 18 \\
\hline \multicolumn{5}{|c|}{ Seats that provide of pre-marriage screening and counseling. } \\
\hline $\begin{array}{c}\text { Maternal and child } \\
\text { health center }\end{array}$ & 280 & 70 & 452 & 75.30 \\
\hline Hospital & 70 & 17 & 60 & 10 \\
\hline Private hospital & 100 & 25 & 28 & 4.70 \\
\hline Social clubs & 18 & 4.50 & 20 & 3.30 \\
\hline University education & 56 & 14 & 56 & 9.30 \\
\hline Don't know & 2 & 0.50 & 0 & 0 \\
\hline
\end{tabular}

Table 4. Percentage division of the nursing and commerce students by their attitude toward pre marriage screening and counseling pre and post

\begin{tabular}{|c|c|c|c|c|c|c|}
\hline \multirow{3}{*}{ Items } & \multicolumn{2}{|c|}{ Pre-marriage counseling } & \multicolumn{2}{|c|}{ Post-marriage counseling } & \multirow{2}{*}{$\begin{array}{c}\begin{array}{c}\text { Nursing } \\
\text { students }\end{array} \\
\mathrm{X}^{2}\end{array}$} & \multirow{2}{*}{$\begin{array}{c}\begin{array}{c}\text { Commerce } \\
\text { students }\end{array} \\
\mathrm{X}^{2}\end{array}$} \\
\hline & $\begin{array}{l}\text { Nursing } \\
\text { students } \\
{[n=400]}\end{array}$ & $\begin{array}{c}\text { Commerce } \\
\text { students } \\
{[n=600]}\end{array}$ & $\begin{array}{l}\text { Nursing } \\
\text { students } \\
{[n=400]}\end{array}$ & $\begin{array}{c}\text { Commerce } \\
\text { students } \\
{[n=600]}\end{array}$ & & \\
\hline & $\%$ & $\%$ & $\%$ & $\%$ & $\mathrm{p}$ & $\mathrm{P}$ \\
\hline \multicolumn{7}{|c|}{ Approval of pre-marriage screening and counseling } \\
\hline Agree & 51 & 36 & 67.50 & 56 & \multirow{3}{*}{$\begin{array}{c}66 \\
0.0121 *\end{array}$} & \multirow{3}{*}{$\begin{array}{c}11.23 \\
0.011^{*}\end{array}$} \\
\hline Neutral & 26 & 32.70 & 21 & 20.70 & & \\
\hline Disagree & 23 & 31.30 & 11.5 & 23.30 & & \\
\hline \multicolumn{7}{|c|}{ Running pre-marriage screening if your future husband asks you to do it } \\
\hline Agree & 34 & 32.70 & 51 & 55 & \multirow{3}{*}{$\begin{array}{c}7.11 \\
0.0102 *\end{array}$} & \multirow{3}{*}{$\begin{array}{c}8.11 \\
0.003^{*}\end{array}$} \\
\hline Neutral & 46 & 41.70 & 30.50 & 28.30 & & \\
\hline Disagree & 20 & 25.60 & 18.50 & 16.70 & & \\
\hline \multicolumn{7}{|c|}{ Conformity that pre-marriage screening is a mandatory procedure before marriage } \\
\hline Agree & 37 & 38 & 51.50 & 50.70 & \multirow{3}{*}{$\begin{array}{c}6.98 \\
0.0119 *\end{array}$} & \multirow{3}{*}{$\begin{array}{c}6.25 \\
0.027\end{array}$} \\
\hline Neutral & 34 & 28.70 & 32.50 & 16 & & \\
\hline Disagree & 29 & 33.30 & 16 & 33.30 & & \\
\hline \multicolumn{7}{|c|}{ Conformity on rules that prevent marriage in case of positive pre marriage screening } \\
\hline Agree & 31 & 25.70 & 40.50 & 43.70 & \multirow{3}{*}{$\begin{array}{c}6.92 \\
0.0309 *\end{array}$} & \multirow{3}{*}{$\begin{array}{c}5.98 \\
0.038^{*}\end{array}$} \\
\hline Neutral & 24.50 & 28.70 & 27.50 & 27.70 & & \\
\hline Disagree & 44.50 & 45.60 & 32 & 28.60 & & \\
\hline \multicolumn{7}{|c|}{ Approval to go to lectures about pre-marriage screening and counseling } \\
\hline Agree & 46.50 & 39 & 57 & 51.70 & \multirow{3}{*}{$\begin{array}{c}7.01 \\
0.011^{*}\end{array}$} & \multirow{3}{*}{$\begin{array}{c}7.25 \\
0.058\end{array}$} \\
\hline Neutral & 29 & 32.70 & 26 & 31.70 & & \\
\hline Disagree & .5024 & 28.30 & 17 & 16.60 & & \\
\hline \multicolumn{7}{|c|}{ Significance of including reproductive health in secondary education } \\
\hline Agree & 39.50 & 38.70 & 54 & 50.70 & \multirow{3}{*}{$\begin{array}{l}1.25 \\
0.36\end{array}$} & \multirow{3}{*}{$\begin{array}{c}6.01 \\
0.031^{*}\end{array}$} \\
\hline Neutral & 34 & 34.70 & 27.50 & 28.30 & & \\
\hline Disagree & 26.50 & 26.60 & 18.50 & 21 & & \\
\hline \multicolumn{7}{|c|}{ Significance of including pre-marriage counseling and care [PMCC] in university education } \\
\hline Agree & 42.50 & 32.70 & 52.50 & 52.70 & \multirow{3}{*}{$\begin{array}{c}6.20 \\
0.025^{*}\end{array}$} & \multirow{3}{*}{$\begin{array}{c}7.09 \\
0.014^{*}\end{array}$} \\
\hline Neutral & 34 & 39 & 27.50 & 27.30 & & \\
\hline Disagree & 23.50 & 28.30 & 20 & 20 & & \\
\hline \multicolumn{7}{|c|}{ Intent to advise the future husband in case of company of chronic diseases in the family } \\
\hline Agree & 43.50 & 42.70 & 62 & 61.70 & \multirow{3}{*}{$\begin{array}{c}6.98 \\
0.025^{*}\end{array}$} & 7.98 \\
\hline Neutral & 35.50 & 32 & 22.50 & 21.70 & & $0.008^{*}$ \\
\hline Disagree & 21 & 25.30 & 15.50 & 16.60 & & \\
\hline
\end{tabular}




\begin{tabular}{|c|c|c|c|c|c|c|}
\hline \multicolumn{7}{|c|}{ Intent to advise the future husband in case of presence of hereditary diseases in the family } \\
\hline Agree & 44.50 & 38.30 & 68 & 66 & \multirow{3}{*}{$\begin{array}{c}12.03 \\
0.001 *\end{array}$} & \multirow{3}{*}{$\begin{array}{c}10.23 \\
0.003^{*}\end{array}$} \\
\hline Neutral & 37 & 40.70 & 20.50 & 19.30 & & \\
\hline Disagree & 18.50 & 21 & 11.50 & 14.70 & & \\
\hline \multicolumn{7}{|c|}{ Approval to continue relation with future husband after infected with hereditary diseases } \\
\hline Agree & 5.50 & 10.70 & 15 & 17.30 & \multirow{3}{*}{$\begin{array}{c}14.42 \\
0.001^{*}\end{array}$} & \multirow{3}{*}{$\begin{array}{c}12.52 \\
0.002 *\end{array}$} \\
\hline Neutral & 26 & 28.30 & 42.50 & 40 & & \\
\hline Disagree & 68.50 & 61 & 42.50 & 42.70 & & \\
\hline \multicolumn{7}{|c|}{ Approval to go through managing in case of some hereditary diseases } \\
\hline Agree & 52.50 & 70.30 & 77 & 81.70 & \multirow{3}{*}{$\begin{array}{c}10.23 \\
0.001 *\end{array}$} & \multirow{3}{*}{$\begin{array}{c}6.98 \\
0.021 *\end{array}$} \\
\hline Neutral & 41 & 15 & 8.50 & 10.70 & & \\
\hline Disagree & 6.50 & 14.70 & 14.50 & 7.60 & & \\
\hline \multicolumn{7}{|c|}{ For fear that of marriage from closed relatives only I will attend genetic screening } \\
\hline Agree & 52 & 60 & 71 & 62.30 & \multirow{3}{*}{$\begin{array}{c}6.98 \\
0.0319 *\end{array}$} & \multirow{3}{*}{$\begin{array}{c}7.110 \\
0.011^{*}\end{array}$} \\
\hline Neutral & 21 & 20.70 & 21 & 25 & & \\
\hline Disagree & 27 & 19.30 & 8 & 12.70 & & \\
\hline \multicolumn{7}{|c|}{ Ready to change decision about marriage based on pre marriage screening results } \\
\hline Agree & 42 & 48.30 & 57.50 & 66 & \multirow{3}{*}{$\begin{array}{c}7.01 \\
0.002 *\end{array}$} & \multirow{3}{*}{$\begin{array}{c}6.89 \\
0.017 *\end{array}$} \\
\hline Neutral & 38.50 & 28.30 & 33 & 24.30 & & \\
\hline Disagree & 19.50 & 23.40 & 9.50 & 9.70 & & \\
\hline \multicolumn{7}{|c|}{ Terminate of marriage in the case of asking for pre marriage screening from the future partner } \\
\hline Agree & 12.50 & 17.30 & 15 & 20.70 & \multirow{3}{*}{$\begin{array}{c}2.32 \\
0.125\end{array}$} & \multirow{3}{*}{$\begin{array}{c}3.10 \\
0.098\end{array}$} \\
\hline Neutral & 32.50 & 24.70 & 36 & 27.30 & & \\
\hline Disagree & 55 & 58 & 49 & 52 & & \\
\hline
\end{tabular}

Table 3 summarizes that $47,50 \%$ to32,0\%from nursing students, what's more, forty-nine point six and twelve point three percent from commerce students individually summarized physician and social specialist as suppliers of pre-marriage screening and counseling. What's more $70.0 \%$ from the medical group contrasted with $75.30 \%$ from the nonmedical group assumed that the maternal and child health center was the set that gives pre-marriage screening and counseling.

Table 4 represents the students' attitudes towards pre-marriage screening and counseling. It can be revealed that there was considerable progress noticed in the students' attitudes from pre to post counseling. This progress was in attitude explanations, for example, approval of pre-marriage screening and counseling from $51.0 \%$ to $67.50 \%$ individually among nursing students and from 36.0 to $56.0 \%$ separately among nonmedical students. Likewise, doing pre-marriage screening if her future partner requests that she do it from thirty-four to fifty-one percent individually amongst nursing students and from $32.70 \%$ to $55.0 \%$ separately among nonmedical students. Even though the commitment to do premarriage screening ranged from 37.0 to $51.50 \%$ separately amongst nursing students, it ranges from thirty-eight to fifty point seven percent individually among nonmedical students. Allowance to directions which delay marriage if found arises an occurrence of positive screening from thirty-one to forty point five percent individually amongst nursing students and from $25.70 \%$ to $43.70 \%$ separately among non-medical students. Concerning the significance of incorporating pre-marriage screening in university education, it was from forty-two points five to fifty-two point five percent separately among nursing students and from $32.70 \%$ to
$52.70 \%$ individually among commerce students. Regarding the goal to tell the future partner if there should be an occurrence of quality of unending sicknesses and hereditary illnesses in the family, it was from forty-three point five to sixty-two percent and forty-four point five to sixty-eight percent individually amongst medical students and from forty-two points seven to sixty-one point seven percent, and from $38.30 \%$ to $66.0 \%$ separately amongst nonmedical students. A minority from the two groups concurred concerning the fulfillment of marriage if the future partner was tainted with hereditary diseasesfrom 5.50 to $15.0 \%$ individually amongst nursing students and from 10.70to $17.30 \%$ separately among nonmedical students. Furthermore, student's attitude lengthened in regards to matters identified with approval to carry out pre-marriage screening in the occasion of consanguineous marriage just and end of marriage if found should arise an occurrence of requesting pre-marriage screening from the prospect partner from 52.0 to $71.0 \%$ and from 12.50 to $15.0 \%$ separately among nursing students contrasted with from sixty to sixty-two point three percent and from $17.30 \%$ to $20.70 \%$ individually among commerce students.

Table 5 shows the aggregate knowledge and attitude score among the two groups. It can be observed that there was a statistically significant improvement regarding total knowledge and attitude scores from pre to posttest amongst the two groups. The high knowledge score expanded from thirty-two points three to fifty-four percent amongst nursing students and from $21.0 \%$ to $41.0 \%$ amongst not nursing students and the difference was statistically significant. Moreover, the positive attitude expanded from 54.700 to $66 \%$ amongst nursing students and from 49.00 to $57.500 \%$ amongst nonmedical students. The difference was statistically significant. 
Table (5). Percentage division of the nursing and commerce students by their total level of knowledge and attitude headed for pre marriage screening and counseling pre and post counseling.

\begin{tabular}{|c|c|c|c|c|c|c|}
\hline \multirow{3}{*}{$\begin{array}{l}\text { Knowledge and } \\
\text { attitude }\end{array}$} & \multicolumn{2}{|c|}{ Pre marriage counseling } & \multicolumn{2}{|c|}{ Post-marriage counseling } & \multirow{2}{*}{$\begin{array}{c}\text { Nursing } \\
\text { students }\end{array}$} & \multirow{2}{*}{$\begin{array}{c}\begin{array}{c}\text { Commerce } \\
\text { students }\end{array} \\
\mathrm{X}^{2}\end{array}$} \\
\hline & $\begin{array}{l}\text { Nursing } \\
\text { students } \\
{[n=400]}\end{array}$ & $\begin{array}{l}\text { Commerce } \\
\text { students } \\
{[n=600]}\end{array}$ & $\begin{array}{l}\text { Nursing } \\
\text { students } \\
{[n=400]}\end{array}$ & $\begin{array}{c}\text { Commerce } \\
\text { students } \\
{[n=600]}\end{array}$ & & \\
\hline & $\%$ & $\%$ & $\%$ & $\%$ & $\mathrm{p}$ & $\mathrm{p}$ \\
\hline \multicolumn{7}{|c|}{ Total level of knowledge } \\
\hline High & 32.30 & 21 & 54 & 41 & \multirow[t]{2}{*}{9.98} & \multirow[t]{2}{*}{8.98} \\
\hline Average & 34.30 & 45 & 34 & 42.50 & & \\
\hline Low & 33.40 & 34 & 12 & 16.50 & $0.001^{*}$ & $0.002 *$ \\
\hline \multicolumn{7}{|c|}{ Total level of attitude } \\
\hline Positive & 54.70 & 49 & 66 & 57.50 & 6.98 & 7.21 \\
\hline Neutral & 22.70 & 32.50 & 21.70 & 22.50 & \multirow[t]{2}{*}{$0.012^{*}$} & \multirow[t]{2}{*}{ 0.003* } \\
\hline Negative & 22.60 & 18.50 & 12.30 & 20 & & \\
\hline
\end{tabular}

Table (6). The association between the nursing and commerce students' age and total level of knowledge and attitude for pre marriage screening and counseling post counseling.

\begin{tabular}{|c|c|c|c|c|c|c|c|c|}
\hline \multirow[t]{2}{*}{ Students' age } & \multicolumn{2}{|c|}{$<20 n=312$} & \multicolumn{2}{|c|}{$20-23 n=688$} & \multicolumn{2}{|c|}{ Total $n=1000$} & \multirow{2}{*}{$\begin{array}{l}\mathrm{X} 2 \\
\%\end{array}$} & \multirow{2}{*}{$\begin{array}{l}\text { p- value } \\
\text { No }\end{array}$} \\
\hline & No & $\%$ & No & $\%$ & No & No & & \\
\hline \multicolumn{9}{|c|}{ Total level of knowledge } \\
\hline High & 180 & 57.60 & 308 & 44.80 & 488 & 48.80 & \multirow{3}{*}{6.01} & \multirow{3}{*}{$0.012^{*}$} \\
\hline Average & 110 & 35.30 & 264 & 38.40 & 374 & 37.40 & & \\
\hline Low & 22 & 7.10 & 116 & 16.80 & 138 & 13.80 & & \\
\hline \multicolumn{9}{|c|}{ Total level of attitude } \\
\hline Positive & 250 & 80.10 & 376 & 54.70 & 626 & 62.60 & \multirow{3}{*}{8.25} & \multirow{3}{*}{$0.002 *$} \\
\hline Neutral & 40 & 12.80 & 180 & 26.10 & 220 & 22.0 & & \\
\hline Negative & 22 & 7.10 & 132 & 19.20 & 154 & 15.40 & & \\
\hline
\end{tabular}

As appeared in table 6, 57.60\% of students who matured under 20 years had elevated level of knowledge scores about pre-marriage screening and counseling, they were contrasted with $44.90 \%$ of the understudy's aged between 20-23 years. The difference was statistically significant $\mathrm{P}=0.012$. Likewise, extensive percent of students ninety points one and fifty-four point seven percent from various ages gather individually resulted in a positive attitude towards pre-marriage screening and counseling. The difference was statistically significant $\mathrm{P}=0.002$.

\section{Discussion}

The outcomes of the present study reported that there was an excess of seventy-five percent seventy-nine point five percent of the nursing age run between 20-23 years when contrasted with sixty-one point seven percent of commerce. A measurable statistical significant was revealed pre and post-program in regards to pre-marriage knowledge identified with the definition, importance, contents, and reasonable time of pre-marriage screening and counseling. Forty-seven point five, thirty-two percent from nursing students and forty-nine point six, twelve point three percent from nonmedical students separately reported physician and social specialist as suppliers of pre-marriage screening and counseling. There is a significant change in the students' attitudes from pre to post counseling. There was a statistical significant in regard to total to knowledge and attitude scores from pre to post counseling amongst the two groups. Fifty-seven point six percent of students who under 20 years had a high level of knowledge scores about pre-marriage screening and counseling contrasted with forty-four point eight percent of the understudy's age extended between $20-23$ years.
Pre-marriage screening and counseling are some of the very important procedures for counteractive action of genetic issues, inherent abnormalities, and basic nursing psychosocial marriage issues ${ }^{14-16}$. Consequences of the present study established that seventy-nine point five percent from nursing and sixty-one point seven percent of commerce students aged between twenty to twenty-three years old, during this age the researcher can strengthen and instruct the students the protective wellbeing carry out for enhancing information and attitude towards pre-marriage screening. In the intervening occasion, medical students will be the prospect human services suppliers who will provide such administrations to people in general through fundamental human services focuses. These outcomes are predictable with Farahat, et al. 2014 who revealed that the age of the considered students ranged from 18 to 24 years old ${ }^{17}$.

In connection to the pre counseling understudy's information related to pre-marriage screening and counseling, the consequences of the current findings reported that less than fifty percent of the students in both groups revealed come to an end right answers in regards to the implication of pre-marriage screening and counseling. Fewer than fifty percent of nursing students contrasted with not exactly fifty percent of the alike group revealed finish appropriate answer related to the significance of pre-marriage screening and guiding. A minority from the two groups be acquainted with the contents of pre-marriage collection. These outcomes are following a study led by King Abdul Aziz University, Jeddah which set up that college students had deficient information about the national premarriage screening programs and less than thirty-three percent from the students competent about problems tried by the pre-marriage screening ${ }^{18}$. The outcomes of the present study were incongruent with Coonrod et al 2009, Gharaibeh and Mater 2009, and a cross- 
sectional study led amongst college students in Nigeria 2006 who found that under sixty-six percent of respondents knew the advantages of family counseling 19,20,21.

With reference to time of pre-marriage screening counseling, less than fifty percent from the two groups respectively specified that it ought to be performed either amid learning years at school or just the once previous to marriage. These outcomes are contradicted with the outcomes of a study done by Al Kindi et al 2012 who reported that most of the members wanted to do it just before marriage. The previous findings were not quite following the current study findings while any dissimilarity was an outstanding disparity in the cultures as well as the contents of health teaching sessions. This may delineate that pre-marriage screening is considered as a helper to comprehensive the course of action of marriage readiness and not as a basic advance ${ }^{22}$.

There was a statistically significant difference between understudy's knowledge pre-test and post-test amongst the two groups. This showed that the health instruction intercession connected in the current study prevailing with regard to enhancing the information of students altogether. These outcomes are in concurrence with diverse investigations directed by Mevsim et al2009, Elsinga et al 2008 and Roa et al $2008^{23-25}$. As for the full of understudy's knowledge score, the present study fulfilled that small percent of medical and nonmedical groups had a prominent level of information score about pre-marriage screening counseling in the pre counseling stage. This absence of information might be credited to lacking indispensable data acquired amid their formal instruction in connection to this particular state of learning. This result concurs with Abd ElGhany et al 2010, who summarized that a small number of quantities of non-nursing and nursing groups had a respectable level of knowledge score about pre-marriage counseling. It is likewise following the study who announced that understudy's learning about the pre-marriage screening program was low in the pretest ${ }^{26}$. As related to the understudy's attitude towards premarriage screening and counseling, the consequences of the present findings demonstrated significance in many items of attitude scale amongst considered groups of students which were identified amid the post counseling. High-quality disposition was seen as related to the appreciation of pre-marriage screening counseling and aim to do it and to tell the future partner if there should be an occurrence of quality of unending and hereditary illnesses in their family. A minority from the two groups allows proceeding with a connection with a future partner on the off chance that he is contaminated with hereditary ailments. Likewise, more than one-half of the two groups were eager to change their choice about marriage in light of pre-marriage screening comes about. These outcomes represent that the students had a decent comprehension of the preventive estimation of pre-marriage screening. The present outcomes are following the consequences of a study done by Farahat et al2014 who said that members' attitudes towards pre-marriage counseling were great fifty-fiftythree nine percent and seven seventy-fourteen trusted that premarriage counseling was helpful ${ }^{17}$. Additionally, Al-Aama. 2011 examined ladies' attitude towards obligatory national pre-marriage screening for the genetic hemolytic issue. The study announced that young women had a more stranded attitude towards the carrying out pre-marriage screenings seventy-three point six percent ${ }^{27}$.

The consequences of the current study were likewise following an examination done by Ibrahim et al. 2011 who illustrated that sixty-four point six percent of students concurred on that. If there should be an occurrence of finding nearness or conveying inborn disorder, marriage choice must be left for the prospect of the couple, along with sixty-seven point one percent of students concurred that when the test comes about show nearness of heritable illnesses, the marriage choice ought to be changed ${ }^{16}$. Besides, Al Kindi et al 2012 revealed that half of the members will choose contingent upon the probabilities of transmitting the infectivity to their youngsters and quarter of them will proceed with marriage for various reasons, for example, not to meddle with God's will, love, and family burden, while just sixteen percent will end commitment and sixteen percent did not recognize what to do ${ }^{22}$. In the post counseling comes about, making pre-marriage screening and counseling as an obligatory strategy before marriage were supported by approximately one half from each group and more than thirtythree percent of them favored setting up laws and controls to prevent marriage in case of positive outcomes. These outcomes are in concord with Al Kindi et al 2012 who detailed similar outcomes ${ }^{22}$. In the current research, more than one section of the students in both groups concurred on the significance of including pre-marriage guiding and health care pre-marriage counseling in auxiliary and college learning. This suggests they are anxious to know more about the subject. These outcomes are steady with Abd El- Ghany et al 2010 who reported that seventy-three percent of students concurred about the considerations of family life directions at school and college ${ }^{26}$. As concerning the general post counseling understudy's attitude towards pre-marriage screening, the outcomes of the present study showed that more or less sixty-six percent of the nursing students had communicated elevating attitude statistically significant toward pre-marriage screening. This might be identified with the idea of their research as wellbeing experts. These outcomes concur with the consequences of various other studies as the assessment done by Ibrahim et al. 2011, summarized that there is a general elevating attitude towards the program; ninety-nine percent of female students either unequivocally concurred or conceded to the significance of pre-marriage screening ${ }^{16}$. Also, an instructive program directed among female students at King Saud University, Riyadh, found that students' attitude was optimistic eighty-one point eight percent of students in the pretest and eighty-five point nine percent in the post-test affirmed the significance of pre-marriage screening ${ }^{27,28}$.

As to association between students' age and the aggregate level of information and attitude toward pre-marriage screening and counseling, directing, the aftereffects of present investigation demonstrated that above one portion of students matured under twenty years old had enormity level of knowledge scores and the majority of them had an inspirational disposition towards premarriage screening and counseling contrasted with forty-four point eight percent and fifty-four point seven percent separately of students matured from twenty to twenty-three years old. This is disillusioning since the elder students should be very much educated and had a positive attitude towards this issue straightforwardly impact the idea of their present and future life. This shows the significance of presenting such data in auxiliary schools and college educational modules to furnish youngsters with critical wellbeing messages. A few studies have as of now noticed that specific statistic factors are effective regardless of whether pre-marriage couples take an interest in pre-marriage screening. These elements incorporate sexual orientation, age, civilization, habitation, learning, and month to month budget, yet these elements just clarify a constrained piece of variety in choices to take an interest ${ }^{29-32}$. In the present research, 
it appears that age impacted the level of knowledge and attitude of students towards pre-marriage screening counseling, these outcomes are following Wang et al. 2013 who emphatically affirmed that age considers a vital component of the attitude and choice to contribute in pre-marriage screening ${ }^{33}$. The consequences of the present research are negated by Abd ElGhany et al 2010 who revealed that the age did not have an impact on the level of knowledge or attitude towards pre-marriage counseling and health concern among students in his examination ${ }^{26}$. The previous findings were not quite following the current study findings while any difference was an outstanding dissimilarity in the cultures as well as health teaching methods.

The restriction of the research; there was not enough time for the examination and counseling in addition to certain students declined to join that study because of their embarrassment.

\section{Conclusion}

It can be consistent that there was a statistically significant in the level of knowledge for all students in the two groups after the health education intercession. While an excess of one half from each group communicated an enormous and positive attitude towards premarriage screening and counseling. More young students had high knowledge and a positive attitude towards pre-marriage screening and counseling. This study aimed to evaluate the effectiveness of wellbeing instruction on the knowledge and attitude of university students on pre-marriage screening and counseling; the research hypothesis was: Female nursing students may have advanced knowledge and attitude scores than female commerce students after receiving pre-marriage counseling; the discussion of the findings support that hypothesis and achieve the aim of the study.

\section{Recommendations}

The suggestions concentrated on the significance of diffusion of information about pre-marriage screening and counseling through formal and informal instruction and media status. Distinguishing in results verify that the importance of pre-marriage screening and counseling and its advantages features of this topic to secondary school and college educational programs. Attention to the overall population has to be raised about the advantages of pre-marriage screening and counseling in an instructive movement. Governmentfunded instruction regarding to testing and its suggestions additionally prescribed. In actuality, experts in hereditary qualities, wellbeing instruction, and the media can cooperate to increment the attention to hereditary infections in the grown-up populace, Television documentaries on specific difficulties and recordings may be watched preceding usage of the pre-marriage screening and counseling. Also, pre-marriage screening and counseling could be stretched out to incorporate a more extensive spectrum of wellbeing and hereditary issue. At long last, the achievement of pre-marriage screening and counseling relies upon satisfactory religious support, government arrangement, training, and guiding. Others with personal stakes incorporate the district community, organizers, nearby\& national government, wellbeing specialists at various levels, and leaders. What's more, pre-marriage screening and counseling could be expanded to incorporate a more extensive range of wellbeing\& hereditary diseases that would enable early recognizable proof and conceivable mediations to anticipate difficulties.

\section{References}

1. Sulaiman A, Suliman A, Al Mishari M, Al Sawadi A Owaidah TM. 2008: Knowledge and attitude toward the hemoglobinopathies pre-marriage screening program in Saudi Arabia: a population-based survey. Hemoglobin; 326: 531-8.

2. Mitwally HH, Abd El-Rahman DA, Mohamed NI. 2000: Premarriage counseling: view of the target group. J Egypt Public Health Assoc;751-2:31-51.

3. Zunyou W, Keming R. 2005: Acceptability of HIV/AIDS counseling. and testing among pre-marriage couples in China. AIDS Educ Prev;171:12-21.

4. Al-Arrayed SS, Hafadh N, Al-Serafi S. 1997: pre-marriage counseling: an experience from Bahrain. East Mediterr Health J;33: 415-9.

5.WHO.1983: Community control of hereditary anemia: memorandum from a WHO meeting. Bull World Health Organ; 611:63-80.

6.WHO.1982: Hereditary anemia: genetic basis, clinic calfea-tures, diagnosis, and treatment. Bull World Health Organ;605:643-60.

7. Melissa LK. 2005: At-risk individuals' awareness, motivation, roadblocks to participation in pre-marriage interventions, and behaviors following completion of the relationship evaluation. Thesis Master of Science. Marriage and Family Therapy Program. Brigham Young University.

8. El-Hazmi MA. 2006: Pre-marriage examination as a method of prevention from blood genetic disorders. Community views. Saudi Med J;279: 1291-5.

9. Alam AA. 2006: Perception of female students of King Saud University towards pre-marriage screening. J Saudi Soc Fam Commun Med;132: 83-8.

10. Adibi P, Hedayati S, Mohseni M. 2007: Attitude towards pre-marriage screening for hepatitis B virus infection in Iran. Med Screen;14: 43-5.

11. Alswaidi FM, O'Brien SJ. 2010: Is there a need to include HIV, $\mathrm{HBV}$, and HCV viruses in the Saudi pre-marriage screening program based on their prevalence and transmission risk factors? J Epidemiol Commun Health;64: 989-97.

12. Editorial. 2009: pre-marriage HIV screening, is ante-natal next? J Infect Public Health;2: 4-6.

13. Statistical Package for Social Science SPSS. Version 16.Chicago: SPSS Inc, Ill.

14. Al-Odaib AN, Abu-Amero KK, Ozand PT, Al-Hellani AM. 2003: A new era for preventive genetic programs in the Arabian Peninsula. Saudi Med J;2411: 1168-75.

15. Al-Aama JY. 2010: Knowledge regarding pre-marriage screening program among university students. Med J;2912: 1649-55.

16. Ibrahim N, Al-Bar H, Al-Fakeeh A, Al Ahmadi J, Qadi M, Al-Bar A, Milaat W.2011: An educational program about pre-marriage screening for unmarried female students in King Abdul-Aziz University, Jeddah. J Infect Public Health, 4:30-40.

17. Farahat T, Shaheen H, Mohamed H, Mohaseb M. 2014: Knowledge and attitude of students in Menoufia University, Shebin Elkomcity toward pre-marriage care in. Menoufia Medical Journal, 27:347352.

18. Al-Aama J, Al-Nabulsi B, Alyousef A, Asiri N, Al-Blewi S. 2008: Knowledge regarding the national pre-marriage screening program among university students in western Saudi Arabia. Saudi Med J. Nov; 2911:1649-53.

19. Coonrod D, Bruce N, Malcolm T, Drachman D, Frey K. 2009: Knowledge and attitudes regarding preconception care in a predominantly low-income Mexican American population. American Journal of Obstetrics and Gynecology; 2006: 686.e1 686.e7.

20. Gharaibeh H, Mater FK. 2009: Young, Syrian adults’ knowledge, perceptions, and attitude to pre-marriage testing. Journal IntNurse Rev; 564:450-5.

21 Moronkola O, Fadairo R. University students in Nigeria.2007: Knowledge and attitude toward sickle cell disease, and genetic counseling before marriage. Int Q Common Health Edu; 261: 85-93.

22. Al-Kindi R, Al-Rujaibi S, Al-Kendi M. 2012: Knowledge and 
attitude of university students towards pre-marriage screening program. Oman Med Journal; 74:291-296.

23. Mevsim V, Guldal D, Gunvar T, Saygin O, Kuruoglu E. 2009: Young people benefit from comprehensive education on reproductive health, Eur. J Contracept. Reprod. Health Care, 142: 144-152.

24. Elsinga J, Jong-Potjer C, Pal-de Bruin M, Cessie S, Assendelft J, Buitendijk S. 2008: The effect of preconception counseling on lifestyle and the behavior before and during pregnancy. Women's Health Issue; 18: 117-S125.

25. Rao R, Lena A, Nair S, Kamath V, Kama A. 2008: The effectiveness of reproductive health education among adolescent girls: A school-based intervention study in Udupi Taluk, Karnataka. Indian. J. Med. Sci., 6211: 439443.

26. Abd El-Ghany G, Gad A, Al - Haddad A. 2010: Knowledge and Attitude about Pre-Marriage Counseling among Hadhramout University Students. Zagazig Nursing Journal; 6 11:46-65.

27. Al-Aama J.2011: Attitude towards mandatory national premarriage screening for hereditary hemolytic disorders. Health Policy; 971:32-7.

28. Alam A. 2012: Perception of female students towards premarriage screening. Journal of Family and Community Medicine; 143:85-7.

29. Alswaidi F, Brien S. 2009: pre-marriage screening programs for haemoglobinopathies, HIV, and hepatitis viruses: review and factors affecting their success. J Med Screen.; 16:22-28.

30. Yuan P, Zhao Y. 2009: Research on the factors and countermeasures of pre-marriage screening in the Xicheng region in Beijing. Chin. family Planning; 6:343-346.

31. Wang Q, Yin W, Gao W, Meng M, Li D. 2010: Analysis of awareness and factors of pre-marriage screening. Chin $\mathrm{J}$ Public Health; 26:495-496.

32.Yu Q, Su B, Zhang J, Liu G, Sun K, Zhang C. 2009: Analysis of the condition after the implementation of voluntary premarriage screening. Chin J Public Health.; 25:871-872.

33. Wang P, Wang X, Fang M, Weele T. 2013: Factors influencing the decision to participate in medical pre-marriage examinations in Hubei Province, Mid-China, BMC Public Health; 13:217.

34.Likert, Rensis 1932. "A Technique for the Measurement of Attitudes". Archives of Psychology 140: 1-55.

35.Hoda, et al., 2015. Improving Knowledge and Attitude of Medical and Non-Medical Students at El Minia University Regarding pre-marriage Screening and Counseling. American Journal of Nursing Science. Vol. 4, No. 5, 2015, pp. 270-279. DOI: 10.11648/j.ajns.20150405.14.

36.Bendig, A. W. 1954. Reliability of short rating scales and the heterogeneity of the rated stimuli. Journal of Applied Psychology, 38, 167-170 